\title{
CONTRIBUTIONS OF CRM APPLICATIONS TO COMPANY PERFORMANCE
}

\author{
DOI: 10.17261/Pressacademia.2020.1230 \\ PAP- V.11-2020(2)-p.7-10
}

Cem Duran ${ }^{1}$, Yeliz Ekinci ${ }^{2}$

${ }^{1}$ Istinye University, Faculty of Economics, Administrative and Social Sciences, Istanbul, Turkey. cduran@istinye.edu.tr, ORCID: 0000-0001-5171-0270

${ }^{2}$ Istanbul Bilgi University, Faculty of Business, Istanbul, Turkey. yeliz.ekinci@bilgi.edu.tr, ORCID: 0000-0001-9478-1271

\section{To cite this document}

Duran, C., Ekinci, Y. (2020). Contributions Of CRM applications to company performance. PressAcademia Procedia (PAP), V.11, p.7-10

Permanent link to this document: http://doi.org/10.17261/Pressacademia.2020.1230

Copyright: Published by PressAcademia and limited licensed re-use rights only.

\begin{abstract}
Purpose- The purpose of this study is to find out the answer to the contributions of CRM applications to sales efficiency, lead management, pipeline, customer tracking, mobility and ensuring customer loyalty. Under this purpose, this study also indicates the reasons of resistance in CRM application use and solutions to them with an overall analyze of CRM's contributions to company performance.

Methodology- The study examines advantages of using CRM for employees in 4 primary basis; Sales Efficiency via Sales Force Automation, Employee Access to Corporate Memory, Mobility, Service and Complaint Management. This study also examines resis tances and solutions against CRM application use.

Findings- The findings of the study indicates that CRM is a mandatory tool for today's companies to prevail competitors in the market by showing what is the unpredictable for the employees, by using the power of data. Also shows how CRM software strengthens the customer engagement and increase customer loyalty and profitability in multi aspects.

Conclusion- CRM software is intended to be used in order to strengthen the relationship with the customer and increase customer loyalty, profitability, increase the productivity of the entire organization, especially the sales and service teams, to ensure collaboration between teams, to institutionalize with a modern technological infrastructure and to ensure the process of transforming from data to wisdom in order to increase corporate memory.
\end{abstract}

Keywords: Customer relationship management, CRM software, company performance.

JEL Codes: M30, M31, L25

\section{INTRODUCTION}

As the competition circumstances for companies are getting more and more difficult every day, the necessities of businesses for new approaches and perspectives are increasing so as to maintain their profitability. Just product features or price discriminations are not enough to increase the profitability of businesses. However, the competition depends already on these two factors. For this reason, companies have become inclined to rediscover the customer who is the main boss and started to listen more to the voice of the customer. The purpose of this is to turn existing customers into loyal customers while creating new customers, and to regain the lost customers. In order to turn towards customer discovery, it is essential to communicate closely with the customer and to get to know the customer and to create customer-specific services and products. We can win the customer with a special and personal service, and he / she can be turned into a loyal customer accordingly.

It is difficult to focus on the customer without having CRM software. For this reason, it is significant for a business to ha ve CRM software. CRM is an information tool which is used to get detailed information about each customer. Customer interactions are maximized with a wellimplemented CRM software. Strong relationships are established with the customer, the predictability of the demand increases, and benefits are gained in internal efficiency, coordination and cooperation (Özilhan, 2010). Corporate memory improves, and data becomes information management over time. CRM benefits not only for sales and service teams which are in direct contact with the customer, but also for finance, marketing and management departments. Because the data obtained is everyone's data and it serves a common purpose. This purpose is the customer satisfaction and customer loyalty. Even a small increase in the percentage of loyal customers will result in high profitability for the firm (Çatı and Koçoğlu, 2011). It depends on personal abilities to get to know the customer without the CRM system and to manage the 
opportunities that may arise according to their needs and expectations. Firms with the aim of institutionalization cannot leave these objectives to the initiative and capabilities of individuals.

\section{ADVANTAGES OF USING CRM FOR EMPLOYEES}

\subsection{Sales Efficiency via Sales Force Automation (SFA)}

Sales teams largely bear the revenue-generating burden of businesses. Whether in the field or in the office, sales teams are constantly busy with sales and pre-sales activities, as well as dealing with many customer-related factors besides sales. In addition, working with sales pressure in routine works reduces the efficiency of sales team members and increases the level of stress that reduces morale motiva tion. The features of sales force automation (SFA) in modern CRM applications help regulate the sales process of individuals with a utomated and accelerated processes fed from the customer database.

In the light of this information, we can say that SFA is CRM software facilities to automatically monitor and remind the all processes of sales and to transform repetitive tasks into automated processes. SFA also reveals the customer acquisition process and cost. SFA software automates customer contacts and routine tasks such as forecast tracking. The purpose of SFA is to make the sales team more concentrated on sales (Chen and Popovich, 2003). SFA assists sales teams in the following headings.

\subsubsection{Lead Management}

The lead indicates the potential customer and can be created from all interaction channels. Sales have not yet been made for the leads or they have not even been offered to the leads. By the CRM system, the leads are recognized as the customer group to focus on for the sales team. The status of the first entries into the system is "a lead". There is very little information required for the sales te am in the lead record. The next process is usually to plan an activity for the lead. This step is assigned as a duty for the salesperson in CRM and it is ensured that the customer is contacted through activities such as appointments, phone call, SMS, and email. After the first contact with the lead, if the salesperson sees a sales opportunity, this lead becomes "qualified". If the lead's wishes and requests are completely differe nt and irrelevant to the work, or if it is a record that will not be considered as a lead, this time the lead will be identified as "unqualified" and recorded for disqualification. No sales effort is made for these records. The lead can only switch to customer status only after the final order is received (Sabnis et al, 2013). The lead can be created with business card information, and may be the person or organization that the salesperson sees and meets as a lead at the fair, on vacation, during travel; namely, in every place in life. Other than that, the lead may have come to the CRM system by filling out forms on the internet or on social media. Lead can be found from multiple channels. The most important issue here is to define the criteria by which these records will be qualified (Ohiomah et al, 2019).

\subsubsection{Pipeline}

Pipeline is one of SFA's most important and effortful processes. The correct data entered in the opportunity records and sales automation done accordingly will minimize the effort spent on unnecessary sales efforts. The right sales process is carried out by spending the sales resources for the right opportunities. The sales opportunity can be applied for the lead as well as for existing customers.

\subsubsection{CustomerTracking}

The sales team will have quick access to all customer records in CRM. Customer tracking includes critical customer data such as the customer's purchase history, current operating patterns, and future needs (Zerbino et al, 2018).

\subsubsection{Team Management}

In modern CRM applications, it is possible to manage many teams, especially sales teams, assign tasks to them, and follow the ir activities. Thanks to team management, sales and targets can be analyzed by regions and teams and evaluated according to time intervals. Since this data can be read in real time, sales team members or sales managers will not need to work separately (Moutot and Bascoul, 2008).

\subsubsection{Offer Management}

Sales teams can see their bids, win-lose rates, and how many revisions a proposal has undergone through CRM. In addition, they can follow the sub-reasons of the results such as winning and losing the history of the offers given. Tracking these jobs without the CRM system requires additional effort and research. CRM systems offer templates, tender files etc. can be given as output documents with CRM data. This automates the time-consuming document preparation process (Gebert et al, 2002).

\subsubsection{Order Management}

Sales team members can view their won bids as orders. While orders reflect the metric that salespeople will be eligible for, this will lead that additional tasks will be created for other business units. For example, when the order is opened, the expiry date of the product can be reported to the service party by a record opened by the service. In addition, orders can be automatically converted into production orders in CRM integrated with ERP system. This kind of automation will totally change according to the way the business operates (Xu et al, 2002). 


\subsubsection{Task Management}

Sales activities refer to the sales efforts made to generate income from the lead or the customer. Many activities such as appointments, presentations, meals, fairs can be considered as sales activities. In addition, service activities are also the activities that should be recorded in CRM. SFA recalls activities or suggests new activities. It creates and monitors routine tasks. This affects sales with an understanding that maintains and sustains the sales effort (Min and Peng-Fei, 2019).

\subsection{Employee Access to Corporate Memory}

Organizational memory, with its simplest definition, means the knowledge of organizations (Şen, 2014). Corporate memory is as old as the existence of the business and is the most effective factor in business decisions. For CRM, corporate memory refers to any cus tomer data that describes customer relationships. This data is the knowledge of the business that is open to sharing and access, but contains records of all relationships with the authorized customer when necessary. CRM systems store, classify and authorize this data until any dele tion and removal procedures are performed. Corporate memory is the application tool of units that want to learn customer-related information from sales to service, from marketing to senior management. Historical data is an important business value that affects decision making in activities such as campaign fiction, sales tactics, grievance management and recovery.

\subsection{Mobility}

The concept of mobility is a concept that is a part of our lives thanks to mobile phones, portable computers and tablets, and expresses the ability to access information via the internet regardless of time and place.

CRM software nowadays has a structure that can work online-offline and can be accessed with portable tools. In this way, employees can respond to their mails and can have access to CRM in the office, on the field or on travel (Dutt and Chauhan, 2019). In this way, while the obstacles in accessing information are eliminated, there is no problem in data entry and transactions. In this way, CRM syste ms change and simplify the way business employees work on mobile. This benefit represents a total benefit for both the company and the employees.

\subsection{Service and Complaint Management}

The most important communication dimension established with the customers is the complaint, request and demand dimension coming from the customer. The quality of management and response speed of customers' complaints and demands directly affect customer satisfaction.

Customer complaints constitute the most up-to-date and direct source of information about the disruptive aspects of the experience offered by the institution and its problematic points (Varnali, 2017). Although most companies consider the number of customers and sales figures in databases as an indicator of customer loyalty, customer complaint management is one of the most important factors that increase customer lifetime value.

Of course, the ideal is to eliminate the complaint before it occurs, but the dialogue with the customer and the positive result gained are very important for the business

A customer who has problems and complaints can become a more enthusiastic and loyal customer than a customer who has never had a problem if his complaint is dealt with professionally and his problem is solved (Barutçugil, 2009).

CRM software includes pages and steps that assist the staff in solving complaints. Responding to any question and complaint that the customer asks about the product and service may involve complicated situations that every employee cannot deal with at all times. An employee who is junior or deals with a complaint without any further specialization may experience difficulties in this regard. At this point, CRM can classify complaints, display the solution information on the complaint screen, provide the result of the complaint and forward it to authorized units for solution, and report them. This, in turn, will reduce the managing the complaints motivation of the staff, which is already difficult in nature, and increase morale motivation.

\section{RESISTANCES AGAINST CRM APPLICATION USE AND SOLUTIONS}

CRM needs data as an information system. There will be data transfer to CRM from many channels such as websites, mobile applications, kiosks, cash registers and pos applications, as well as data supplied to the system by company employees. At this point, since CRM usage will enrich the data, it becomes indispensable in the company and some resistance related to usage occurs. Firms with a CRM software culture can solve the crisis by making minor software or design improvements in this regard, but the crisis will be deeper in busines ses that have not used CRM before or started using new CRM (Fredrick and Christopher, 2019).

It is possible to list the reasons and solutions of resistance to using CRM as follows.

- Using CRM is not seen as a duty and responsibility: Many employees see the use of CRM as a burden on their core business. The crisis point on this issue should be determined and eliminated. At this point, improvements should be made on unnecessary data points and imperatives. In addition, the top management decisions, their reasons and the benefits of using CRM should be shared with the employees. In this context, consensus should be reached on common goals. 
- Being accustomed to the old system: Employees want to enter data in the simplest and most familiar way. However, it is very important to enter data in a structured and classified form in terms of information management. Office programs such as Excel and Word, traditional methods such as Notebook, Post-it, and Agenda will cause data loss.

- System errors and complaining about system performance: CRM software is open to code or logic errors. These errors can cause frustration for users who use the system constantly. Therefore, system errors should be dealt with in a fast and effective way, and they should not cause new problems while eliminating the problem.

- Complaining about excessive procedures: Sometimes a short job can get complicated and last longer due to many screens. In this case, it is important to present the processes as automatically as possible and the interfaces to the user in the simplest form.

\section{CONCLUSION}

CRM software is an auxiliary tool that relieves the burden on company employees and shows what they cannot predict. A CRM constructed in this way increases employee productivity and helps the company increase its profitability. The suggestions of all internal stakeholders and CRM projects carried out with an IT department dominating business processes are successful. CRM software is software that is becoming more and more popular all over the world and increasing its total income. For this reason, the world's leading software companies produce CRM software. These produced software are verified and generally accepted systems and they are open to customization while re sponding to business needs in general. In addition, it can bring discipline and structural arrangements to the business organization. Technological infrastructure and intellectual knowledge increase.

As a result of the research, CRM software is intended to be used in order to strengthen the relationship with the customer and increase customer loyalty, profitability, increase the productivity of the entire organization, especially the sales and service teams, to ensure collaboration between teams, to institutionalize with a modern technological infrastructure and to ensure the process of transforming from data to wisdom in order to increase corporate memory.

\section{REFERENCES}

Barutçugil, P. (2009). Müşteri İlişkileri ve Satış Yönetimi. Kariyer Yayıncılık.

Chen, I. J., \& Popovich, K. (2003). Understanding customer relationship management (CRM) People, process and technology. Business process management journal, 9(5), 672-688.

Çati, K., \& Koçoğlu, C. M. (2008). Müşteri Sadakati İle Müşteri Tatmini Arasindaki iliş̧kiyi Belirlemeye Yönelik Bir Araştirma . Selcuk University Social Sciences Institute Journal, 19.

Dutt, H., \& Chauhan, K. (2019). Using flexibility in designing CRM solution. Global Journal of Flexible Systems Management, 20(2), $103-116$.

Fredrick, K., \& Christopher, D. (2019). Investigative analysis of CRM System Implementation and the challenges attached to its integration into existing ERP System. From an Organization Perspective: A case study of a Freight Forwarding Company in Sweden.

Gebert, H., Geib, M., Kolbe, L., \& Riempp, G. (2002). Towards customer knowledge management: Integrating customer relationship management and knowledge management concepts. In The Second International Conference on Electronic Business (ICEB 2002) (pp. 296298).

Min, J. I., \& Peng-Fei, J. I. (2019). Research on the Marketing Management System of Companies Using CRM System. DEStech Transactions on Social Science, Education and Human Science, (icesd).

Moutot, J. M., \& Bascoul, G. (2008). Effects of sales force automation use on sales force activities and customer relationship management processes. Journal of Personal Selling \& Sales Management, 28(2), 167-184.

Ohiomah, A., Andreev, P., Benyoucef, M., \& Hood, D. (2019). The role of lead management systems in inside sales performance. Journal of Business Research, 102, 163-177.

Özilhan, D. (2010). Müşteri İlişkileri Yönetimi (MiY) Uygulamalarının İşletme Performansına Etkileri. Gümüşhane Üniversitesi Sosyal Bilimler Enstitüsü Elektronik Dergisi, 1(1).

Sabnis, G., Chatterjee, S. C., Grewal, R., \& Lilien, G. L. (2013). The sales lead black hole: On sales reps' follow-up of marketing leads. Journal of marketing, 77(1), 52-67.

Şen, Y. (2014). Örgütsel Hafıza Sistemi ve Bir Model Önerisi:Karar Verme Üzerindeki Rolü Ve Bir Uygulama. İstanbul: Doktora Tezi.

Varnalı, K. (2017). Müşteri Deneyimi. İstanbul: MediaCat.

Xu, Y., Yen, D. C., Lin, B., \& Chou, D. C. (2002). Adopting customer relationship management technology. Industrial management \& data systems, 102(8), 442-452.

Zerbino, P., Aloini, D., Dulmin, R., \& Mininno, V. (2018). Big Data-enabled customer relationship management: A holistic approach. Information Processing \& Management, 54(5), 818-846. 